\title{
Peran TTP Cigombong pada Usaha Ternak Ayam Kampung KUB sebagai Upaya Meningkatkan Pendapatan Peternak
}

\author{
The Role of Cigombong TTP in KUB Kampung Chicken Business in Efforts to Increase \\ Farmers' Income
}

\section{S. Rusdiana dan L. Praharani}

Balai Penelitian Ternak Ciawi-Bogor Po.Box. 221

Corresponding email: s.rusdiana20@gmail.com

\begin{abstract}
The study aimed to determine the role of Cigombong TTP in KUB village chicken farming in an effort to increase the farmer's density. Various problems and problems that are often faced by Cigombong TTP, should be the focus of attention. In such away, that the Cigombong TTP can be played a large role as a vehicle for the development of KUB village chicken farming. Commercially oriented free-range chicken businesses are needed for more detailed planning and handling so that businesses can benefit. The study was conducted 2017, the core farmers and chicken breeders of the KUB village were located in the Cigombong TTP Tugu Jaya Village, Cigombong District, Bogor Regency. Core breeders and breeders of plasma breeders have pioneered the business of KUB native chickens intensively, as seeds, cut and eggs (DOC). Expenditures and income of farmers can be calculated based on the $\mathrm{B} / \mathrm{C}$ ratio, namely the balance of profit and production costs. The results of the research show, the selling value of chicken farms of KUB villages at the age of 8 weeks is a net profit of Rp. 995,000,-/ farmer, the value of $\mathrm{B} / \mathrm{C}$ ratio is 1.3 . The results of the analysis of KUB chicken breeding business at the age of 8 week, are economically financially feasible to be recultivated.
\end{abstract}

Key words: TTP, KUB free-range chicken business, farmer's income

\begin{abstract}
ABSTRAK
Penelitian bertujuan untuk mengetahui peran TTP Cigombong pada usaha ternak ayam kampung KUB dalam upaya meningkatkan penapatan peternakk. Berbagai kendala dan permasalahn yang sering dihadapi oleh TTP Cigombong, seyogyanya menjadi fokus perhatian, sehingga TTP Cigombong dapat dimainkan peran besar sebagai wahana untuk pengembangan usaha ternak ayam kampung KUB. Usaha ayam kampung yang berorientasi komersial sangat diperlukan perencanaan dan penanganan yang lebih detail, agar usaha mendapatkan keuntungan. Penelitian dilakukan pada tahun 2017, peternak inti dan peternak plasma ayam kampung KUB dilokasi TTP Cigombong Desa Tugu Jaya Kecamatan Cigombong Kabupaten Bogor. Peternak inti dan peternak Peternak plasma telah melakukan rintisan usaha ayam kampung KUB secara intensif, sebagai bibit, potong dan telur (DOC). Pengeluaran dan pendapatan peternak dapat dihitung berdasarkan $\mathrm{B} / \mathrm{C}$ ratio, yaitu imbangan keuntungan dan biaya produksi. Hasil penelitan menunjukkan, nilai jual ternak ayam kampung KUB umur 8 minggu keuntungan bersih sebesar Rp.995.000,-/peternak nilai B/C ratio 1,3. Hasil analisis usaha pemeliharaan ternak ayam kampung KUB pada umur 8 minggu, secara ekonomi finansial layak untuk diusahakan kembali.
\end{abstract}

Kata kunci: TTP, usaha ayam kampung KUB, pendapatan peternak

\section{PENDAHULUAN}

Program pembangunan dan pengembangan Taman Sains dan Teknologi Pertanian (TSTP) atau Taman Teknologi Pertanian (TTP), sangat tepat untuk dilaksanakan oleh Badan Litbang Pertanian,
Kementerian Pertanian. Penyebar luasan dapat dilkakukan melalui proaktif promosi teknologi pada pengelolaan budidaya ternak oleh lembaga penelitian seperti Balitnak dan BPATP. Dengan demikian sub sektor peternakan dapat dikembangkan melalui konsep kawasan agropolitas, dan khususnya 
komoditas ternak ayam kampung. (Loing dan Makalew, 2016). Aktifitas dan pendayagunaan sumberdaya peternak yang tersedia, dapat diberdayakan kemampuannya untuk usaha ternak ayam kampung KUB. Peternak dapat memperoleh hasil pendapatan dari usahanya. Peternak memelihara ayam kampung KUB, sebagai suatu cara untuk menyimpan uang dan juga sebagai suatu pekerjaan yang memuaskan peternak.Tentunya akan sangat membantu para peternak, penyuluh, Dinas Pemerintah daerah, karena lembaga penelitian sebagai penemu teknologi yang lebih menguasai sainnya (Angraeni 2016).

Upaya untuk mengembangkan ternak ayam kampung KUB di kawasan TTP dan di luar TTP, agar lebih meningkatkan pendapatan peternak dan juga populasi ternak ayam kampung KUB meningkat. Untuk menghasilkan banyak inovasi teknologi pertanian dan perternakan TTP Cigombong siap untuk menyebar luaskan kepada masyarakat peternak, hasil inovasi teknologi ternak unggul Balitnak ayam kampung KUB. Pada umumnya masyarakat di pedesaan memelihara ayam kampung, skala kecil secara intensif (Nurhapsa et al., 2017) Inovasi teknologi tepat guna sangat diperlukan oleh peternak untuk meningkatkan produk peternakan, dalam mendukung perkembangan ekonomi masyarakat. Peternakan dapat diintegrasikan dengan model pengembangan Taman Teknologi Pertanian (TTP) atau agro techno park dan Taman Sains Pertanian (TSP) atau agro science park, dan pasar tradisional. Taman Sains Pertanian (TSP) berfungsi sebagai tempat pengembangan invensi bidang pertanian dan peternakan serta berwawasan agribisnis (Kementan, 2012).

Menerapkan teknologi dari praproduksi sampai pemasaran, pengkajian inovasi teknologi dan rekayasa kelembagaan, penciptaan iptek oleh akademisi dan peneliti sebagai inkubator, dan penyedia teknologi solutif di TTP. Sementara, TTP dikembangkan dengan fungsi antara lain sebagai tempat pengembangan dan penerapan inovasi teknologi berwawasan agribisnis serta tempat pelatihan, pemagangan, kemitraan usaha, pusat diseminasi teknologi dan advokasi bisnis. Sejak terbentuknya instansi pemerintah yang menangani subsektor peternakan, tidak sedikit berbagai informasi dan teknologi yang direkomendasikan untuk dapat diterapkan. Meskipun sifatnya dinamis dari tahun ke tahun sesuai dengan perkembangan negara dan bangsa kita, yang tidak sedikit dipengaruhi perkembangan dunia. Dengan menggunakan teknologi dan inovasi, maka sebagian besar masyarakat peternak, akan meningkat pada kondisi keluarga yang cukup. Peternak di pedesaan sebagian besar menempati keluarga berpenghasilan rendah, sebagian kecil dan berpenghasilan menengah (Anggraeni, 2016).

Berbagai upaya pemerintah dan/atau lembaga swadaya masyarakat untuk meningkatkan pendapatan dan kesejahteraan peternak dapat dilakukan, melalui berbagai pendekatan budidaya ternak. Namun adanya dinamika perkembangan industri peternakan, tentunya tidak sedikit upaya-upaya modifikasi sistem budidaya itu sendiri yang secara dinamis harus dikembangkan dengan mengikuti perkembangan secara nasional. Konsep pengembangan peternakan modern oleh karenanya dapat ditargetkan melalui pendekatan pengembangan dan penerapan inovasi teknologi peternakan yang terintegrasi dengan komoditas pertanian lainnya dalam kawasan agribisnis TTP ataupun TSP. Namun demikian, keberhasilan Taman Sains Pertanian (TSP) dan Taman Teknologi Pertanian (TTP) dalam menyebar luaskan inovasi teknologi pertanian kepada masyarakat juga bergantung pada keterlibatan dan komitmen Pemerintah Daerah baik di tingkat provinsi maupun di tingkat kabupaten/kota.

Taman Teknologi Pertanian (TTP) Cigombong yang menetapkan ternak lokal sebagai salah satu komoditas unggulan untuk dikembangkan di TTP dan kawasannya adalah ternak Ayam KUB, Kambing perah dan domba. Berdasarkan permasalahan tersebut diatas, perlu digali potensi sumbersumber pertumbuhan ekonomi dari usaha 
peternakan, sehingga dapat distribusikan sebagai sumber daya yang dapat diperbaharui dan menghasilkan keuntunagn bagi peternak. Mengingat ketersediaan lahan dan sumberdaya manusia yang relatif cukup. Namun sebagian besar masyarakat peternak di pedesaan berprilaku statis, sehingga apabila ditawarkan teknologi tepat guna dapat meningkatkan pengetahuan dalam usaha ternak. Untuk melaksanakan usaha ternak, perlu adanya kelompok peternak agar teknologi yang akan diterapkan kepada peternak dapat diterima dengan baik. Pembentukan kelompo peternak yang berorientasi pada agroindustri hulu dan hilir, dapat diperkenalkan sebagai peluang usaha bagi peternak. Berbagai kendala dan permasalahn yang sering dihadpi oleh TTP seyogyanya menjadi fokus perhatian, sehingga TTP Cigombong dapat dimainkan peran besar sebagai wahana untuk pengembangan usaha ternak ayam kampung KUB. Tujuan tulisan ini adalah untuk mengetahui tingkat kelayakan usaha ternak ayam kampung KUB pada peternak plasma di sekitar lingkungan TTP Cigombong.

\section{Dasar Pertimbangan}

Ayam kampung KUB, telah berkembang secara luas di berbagai wilayah Indonesia. Kemampuan ternak ayam kampung KUB sudah dapat beradapasi dengan lingkungan wilayah sekitar pemeliharaan. Penyebaran ternak ayam kampung KUB, saat ini sudah hampir di seluruh Propinsi di Indonesia. Ayam kampung lokal menyebabkan keberadaannya sudah dapat diakui oleh masyarakat sebagai bagian kehidupan yang tak terpisahkan sebagai pendapatan harian (Wibowo dan Sartika 2011). Ayam lokal telah berhasil membuktikan 41 rumpunyang hidup di Indonesia baik asli maupun pendatang, yang sudah menempuh siklus produksi minimal 3 generasi (Sartika dan Gunawan 2007). Selain itu pula ayam kampung lokal mempunyai potensi pasar yang cukup besar, bakan mempunyai segmen pasar tersendiri, daging ayam kampung mempunyai tekstur yang khas sehingga disukai oleh masyarakat di
Indonesia. Usaha ternak ayam kampung sudah dikenal dengan pola usaha ektensif, semi intensif dan intensif.

Sartika dan Gunawan (2007) bahwa, budidaya ayam kampug sebagian besar $70 \%$ dipelihara secara tradisional dan 30\% dipelihara dengan mengikuti program intensifikasi ayam buras (INTAB). Pengembangan usaha ayam kampung dapat ditempuh melalui berbagai cara, namun tergantung pada peternak dalam melakukan usahanya, yang mendasari komersial atau subsistem. Pola-pola tersebut sudah banyak diterapkan oleh peternak dipedeaan, baik skala kecil, menengan dan besar. Sedangkan untuk usaha intensif dengan tujuan komersial maka diperlukan persiapan yang matang, yaitu teknologi, pengetahuan dan modal. Kebutuhan pada usaha ternak ayam sepenuhnya tergantung dari peternak, sehingga peternak menanggung biaya produki pada usaha ternak ayam kampung. Usaha yang bersifat komersial perlu adanya perencanaan yang matang, sehingga dapat dievaluasi atas kegiatan yang sedang berlangsung untuk dilanjutkan ata hentikan (Wibowo dan Sartika 2011).

Sektor peternakan, komoditas yang dituntut untuk mendukung kebutuhan pangan berupa susu, daging dan telur sebagai sumber protein hewani asal ternak (Muzayyanah et al., 2016). Semakin meningkat pendapatan masyarakat, pengetahuan tentang kebutuhan gizi, serta perubahan selera masyarakat, maka akan cenderung mengarah pada kebutuhan protein hewani akan meningkat (Ilham et al., 2008) dan (Wiranata et al., 2017). Sektor peternakan memiliki peran yang sangat strategis, dalam upaya untuk kecukupan pangan, menyerap tenaga kerja, meningkatkan pendapatan dan mencerdaskan sumberdaya manusia yang berkualitas melalui konsumsi dan produk yang dihasilkan. (Adawiyah dan Rusdiana 2015). Ternak ternak ayam kampung KUB merupakan ternak yang mudah diusahakan dan juga memiliki potensi yang dapat dikembangkan untuk meningkatkan pendapatan keluarga petani peternak. Tenaga kerja peternak cukup tersedia dan sebagai 
faktor penting pada usaha ternak ayam kampong.

Sejalan dengan program pembangunan peternakan nasional. untuk mewujudkan ketahanan pangan asal ternak berbasis sumber daya lokal secara konsisten terus diupayakan oleh Pemerintah (Anggraeni, 2016). Sejalan dengan pertumbuhan ekonomi yang terus diupayakan meningkat, bidang peternakan dapat dijadikan alternatif sebagai pengungkit pertumbuhan ekonomi baru (Supriyati dan Erma 2006) dan (Kusnadi 2011). Kemandirian dan kecukupan akan pangan asal hewani menjadi program Pemerintah yang paling utama, sehingga ternak ayam kampung KUB sangat layak untuk dikembangkan. BPATP dan Balitnak adalah salah satu Unit Pelaksana Teknis yang bertanggungjawab kepada Badan Litbang Pertanian, Kemneterian Pertanian. Salah satu upaya yang dilakukan Kementan adalah mengembangkan kawasan sentra produksi komoditas unggulan yang diintegrasikan dengan model pengembangan Taman Teknologi Pertanian (TTP) atau agro techno park dan Taman Sains Pertanian (TSP) atau agro science park, dan pasar (Badan Litbang Pertanian 2015).

Pengembangan invensi bidang pertanian dan peternakan yang berwawasan agribisnis peternakan agar dapat produksi ternak sampai pemasaran. Inovasi teknologi dan rekayasa kelembagaan, dan penciptaan iptek oleh akademisi dan peneliti sebagai inkubator, dan penyedia teknologi solutif di TTP agar berkembang dengan baik. Program TTP Cigombong dikembangkan dengan fungsi antara lain sebagai tempat pengembangan dan penerapan inovasi teknologi berwawasan agribisnis serta tempat pelatihan, pemagangan, kemitraan usaha, pusat diseminasi teknologi dan advokasi bisnis.

\section{MATERI DAN METODE}

Penelitian dilakukan di TTP Cigombong, Desa Tugujaya Kecamatan Cigombong Kabupaten Bogor, Propinsi Jawa
Barat. Penelitian dilakukan pada tahun 2017, pada peternak inti dan peternak. Peternak inti dan peternak plasma telah melakukan usaha rintisan pembesaran ayam kampung KUB secara intensif, sebagai bibit, potong dan telur (DOC). Lokasi penelitian didukung dengan sarana prasarana yang cukup, yaitu gedung kantor, aula pertemuan, pelatihan, kandang ayam kampung KUB, kandang kambing dan kandang ternak domba hasil penelitian dari Balai Penelitian Ternak Ciawi-Bogor. TTP Cigombong didukung degan kondisi lingkungan yang strategis dan mudah dijangkau oleh kendaran roda dua dan roda empat. Peran TTP Cigombong sebagai ajang ilmu yang dapat di kembangkan melalui teknologi inovasi hasil rekayasa Balitnak.

\section{Pengumpulan Data}

Data dikumpulkan dengan cara pengamatan langsung dilapang dan rekording data dengan metoda survey dengan cara wawancara, teknis dan ekonomis, terhadap sebanyak 14 peternak inti dan peternak plama ayam kampong KUB. Usaha pengembangan ayam kampung KUB dengan cara pemeliharaan 8 minggu, yang berorientasi komersial, sehingga sangat diperlukan perencanaan yang cukup matang. Penanganan pada ayam kampung KUB yang lebih detail, agar usaha ternak ayam kampung KUB yang ada di inti dan plasma mendapatkan keuntungan yang optimal. Peternak inti dan peternak plasma telah melakukan usaha rintisan pembesaran ayam kampung KUB secara intensif. Usaha tersebut untuk tujuan sebagai bibit, potong dan telur (DOC). Peternak inti mempunyai ternak ayam kampung KUB rata-rata sebanyak antar 500-1000 ekor berpariasi umur jantan dan betina. Sedangkan peternak plasma mempunyai ayam kampung KUB dengan rata-rata kepemilikan sebanyak antara 100-500 ekor, jantan dan betina berpariasi umur.

Teknik penarikan hasil penelitian pada peternak inti dan lasma digunakan melalui pencatatan data produksi setiap hari, kemudian dihirung berdasarkan waktu 
analisa usaha satu tahun. Peternak inti dan peternak plasma menggunakan teknologi dan inovasi anjuran dari Balitnak dan dari BPATP, yang diintroduksikan melalui peternak intiterlebih dahulu, kemudian dilanjutkan teknologinya kepada peternak plsama. Jenis dan data yang dibutuhkan dalam penelitian ini adalah analisis data primer dan data sekunder. Materi atau data yang dikumpulkan adalah semua data penggunaan input produksi pada usaha ternak ayam kampung KUB. Data primer diperoleh dari hasil wawancara dan hasil pengisian kuisioner langsung dari peternak plasama. Sedangkan data sekunder diperoleh dari Dinas Pertanian dan Peternakan setempat, TTP Cigombong, juga dari hasil penelitian yang sudah diterbitkan baik melalui prosiding, jurnal, buku, serta dari informasi dan dari pemikiran serta ide-ide sendiri.

Data primer dan data sekunder yang diperoleh dari peternak inti dan peternak plasma, kemudia ditabulasi dan dianalisis secara deskripif, kuantitatif dan analisis ekonomi $\mathrm{B} / \mathrm{C}$, diuraikan berdasarkan hasil dalam bentuk tabel-tabel dan sub-sub kalimat, sesuai dengan tujuan penelitian. Menurut Rosganda dan Rusdiana (2012), bahwa untuk menghitung nilai ekonomi pada usaha ternak ayam kampung dapat menggunakan melalui pendekatan aspek teknis dan aspek nilai sosial ekonomi. Pengeluaran dan pendapatan peternak dapat dihitung berdasarkan metoda $\mathrm{B} / \mathrm{C}$ yaitu imbangan keuntungan dan biaya produksi (Krismawati dan Andy 2006) dan (Zakaria 2014). Untuk kondisi peternak di TTP dan diluar TTP diperlukan pendekatan secara ekonomi, dalam perhitungannya sangat berbeda. Asumsi untuk biaya pembelian bibit, pakan, tenaga kerja dapat dihitung berdasarkan waktu satu tahun.

\section{HASIL DAN PEMBAHASAN}

\section{Daya Dukungan Wilayah TTP Cigombong}

Kegiatan TTP Cigombong ditempatkan di Desa Tugu Jaya, Kecamatan Cigombong, Kabupaten Bogor dibawah tanggung jawab pelaksanaan Balai Pengelolaan Alih Teknologi Pertanian (BPATP), yang sat ini sudah dialihtugaskan mulai tahun 2018 ke Pemda Kabupaten Bogor. Namun hal tersebut BPATP dan Balitnak lingkup Badan Litbang Pertanian masih tetap mengkaji dari kegiatan TTP Cigombong. Sampai tahun 2017 sudah diintrodusikan sejumlah ternak unggulan dari Balitnak ke TTP Cigombong yaitu: ayam KUB, domba Compass, Agrinak dan kambing perah yaitu sapera dan Anglo-PE. TTP Cigombong diharapkan dapat menjadi show window bagi pengembangan ternak unggulan Balitnak. Perlu dikembangkan dengan berorientasi bisnis, sehingga masyarakat sekitarnya dapat merasakan adanya tambahan nilai ekonomi dan bisa meningkatkan kesejahteraan melalui pengembang biakan dan usaha peternakan. Pengembangan TTP Cigombong sampai dengan pertengahan tahun 2018 kelompok peternak ayam kampung KUB sudah berjalan dengan baik.

Kelompk peternak plasma sampai tahun 2017 sudah menjadi 14 peterak binaan TTP Cigombiong. Saat ini sudah melakukan koordinasi secara aktif dengan tim peneliti dan pelaksana Balitnak untuk mendapatkan model pembangunan TTP dan kawasanan pengembangan peternakan yang tepat berdasarkan hasil identifikasi potensi lokasi, komoditas ternak, teknologi dan model kelembagaan yang dikembangkan secara terintegrasi berorientasi agribisnis. Kelembagaan yang dibentuk dari para kooperator pelaksana kegiatan TTP saat ini sudah dilihat dan diperbaiki tentang kualifikasi, kinerja dan komitmen dalam pelaksanaan pengembangan TTP Cigombong dengan basis komoditas peternakan. Adanya perbaikan kelembagaan ini diharapkan para pelaku usaha dapat lebih bekerjasama dalam melakukan pemeliharaan ternak secara lebih intensif dan serius, serta berkoordinasi dengan berbagai pihak untuk mengembangkan TTP tersebut sebagai core bisnis peternakan di wilayahnya.Ternak ayam kampung lokal KUB sangat cocok untuk kembangkan di seluruh wilayah 
Indonesia dan juga sebagai ayam unggul Badan Litbang Pertanian, Kementerian Pertanian.

\section{Peran TTP Cigombong Memberikan Teknologi Peternakan}

Program pembangunan peternakan nasional untuk mewujudkan ketahanan pangan asal ternak berbasis sumber daya lokal secara konsisten terus diupayakan Pemerintah. Sejalan dengan pertumbuhan ekonomi yang terus diupayakan meningkat, bidang peternakan dapat dijadikan alternatif sebagai pengungkit pertumbuhan ekonomi. Peran TTP Cigombong selain untuk mengembangkan inovasi teknologi juga menegmbangkan usaha peternakan dan pertanian, dan tujuannnya untuk mendapatkan nilai ekonomi peternak meningkat. Kemandirian akan pangan asal hewani dan nabati menjadi program TTP Cigombong yang sangat layak untuk dikembangkan di Indonesia. Balitnak adalah salah satu Unit Pelaksana Teknis Badan Penelitian dan Pengembangan Pertanian yang bertanggung jawab kepada Pusat Penelitian dan Pengembangan Peternakan.

Berdasarkan surat Keputusan Menteri Pertanian Nomor 71/Kpts/OT.210/1/2002 Tanggal 29 Januari 2002, bahwa Balai Penelitian Ternak merupakan Unit Pelaksana Teknis dibidang Penelitian dan Pengembangan Peternakan yang mempunyai tugas pokok melaksanakan penelitian pada komoditas ternak: (i) Unggas dan Aneka Ternak, (ii) Sapi Perah dan Sapi Dwiguna, (iii) Kerbau, (iv) Domba, (v) Kambing Perah (vi) Tanaman Pakan Ternak. Untuk mendukung usaha peternakan yang berdaya saing dan berkelanjutan, Balitnak melakukan serangkaian kegiatan penelitian untuk pengembangan IPTEK yang bertujuan melakukan peningkatan efisiensi dan produktivitas usahaternak (Badan Litbang Pertanian 2015). Banyak inovasi teknologi dan ternak unggul yang sudah dihasilkan dari porses kegiatan penelitian Balitnak, diuaikan sebagai berikut.

\section{Pendampingan Komoditas Ternak}

Program TTP pada tahun 2016 adalah merupakan tahun ke 2, dimana tahun pertama adalah pembangunan intrastruktur dan perancangan komoditas yang akan dikembangkan di lokasi. Didalam pendampingan ini Balitnak juga ikut pula dalam perancangan pengembangan komoditas ternak yang prospektif merupakan titik ungkit mendukung TTP yang dibangun. Komoditas unggulan Balitnak yakni ternak ruminansia adalah Sapi, Domba dan kambing, sedangkan ternak unggas adalah Ayam Kampug nggul Balitbangtan (KUB), dan itik. Ayam KUB dikembangkan pada lokasi TTP di Cigombong, yang difokuskan pada pola pembibitan yang dilakukan di kandang pada areal TTP, yang pada perkembangannya dikembangkan pada masyarakat. Untuk mendukung kegiatan tersebut di TTP telah dibangun 2 unit kandang dengan kapasitas 2.500 ekor, untuk kegiatan reproduksi penghasil DOC, telur konsumsi, dan ayam siap potong. Prospek pengembangan ayam KUB juga prospektif dikembanghkan di TTP Sungai Mandau, tetapi pada pendampingan belum dilakukan introduksi. Komoditas ternak lainnya (unggas) adalah itik yang dirancang di lokasi TTP Sungai Mandau dan Kalsel, tetapi masih terbatas perencanaan dan belum pada tahapan introduksi komoditas.

\section{Pendampingan Pengembangan Komoditas Ternak}

Disamping pengembangan komoditas dalam mendukung kinertja TTP, juga dilakukan pendampingan teknologi, yang disesuaikan dengan kondisi dan kebutuhan spesifik lokasi keberadaan TTP. Pendampingan Balitnak yang dilakukan khususnya untuk komoditas ayam KUB adalah teknologi pembibitan, dimana pengembangan yang dilakukan adalah melakukan kegiatan inti plasma. Kegiatan dari aspek inti adalah program penetasan sebagai penghasil DOC yang dilakukan di stasiun lokasi TTP dengan pembangunan kandang ayam sesuai kebutuhan dan dikerjakan di TTP, sebagai ajang 
pembelajaran oleh masyarakat, yang kemuduian dihasilkan DOC untuk dikembangkan di masyarakat sekitar sebagai usaha di masing-masing peternak. Dalam pengembangan teknologi ayam KUB, TTP Cigombong sudah merancang program "Biosecurity", saat ini sudah dapat digunakan. Disamping inovasi teknologi budidaya, reproduksi (IB), dan untuk kelembagaan pemasaran hasil dilakukan kerjasama dengan perusahan peternakpeternak diluar TTP juga sudah berjalan dengan baik.

Kerjasama usaha yama kampung KUB sebagai mitra bisnis dalam pengadaan DOC dan pemasaran bibit dan telur. Kondisi dan peta TTP Cigombong yang saat ini sudah milik Pemda Kabupaten Bogor, dapat dilihat pada Gambar 1 dan 2.

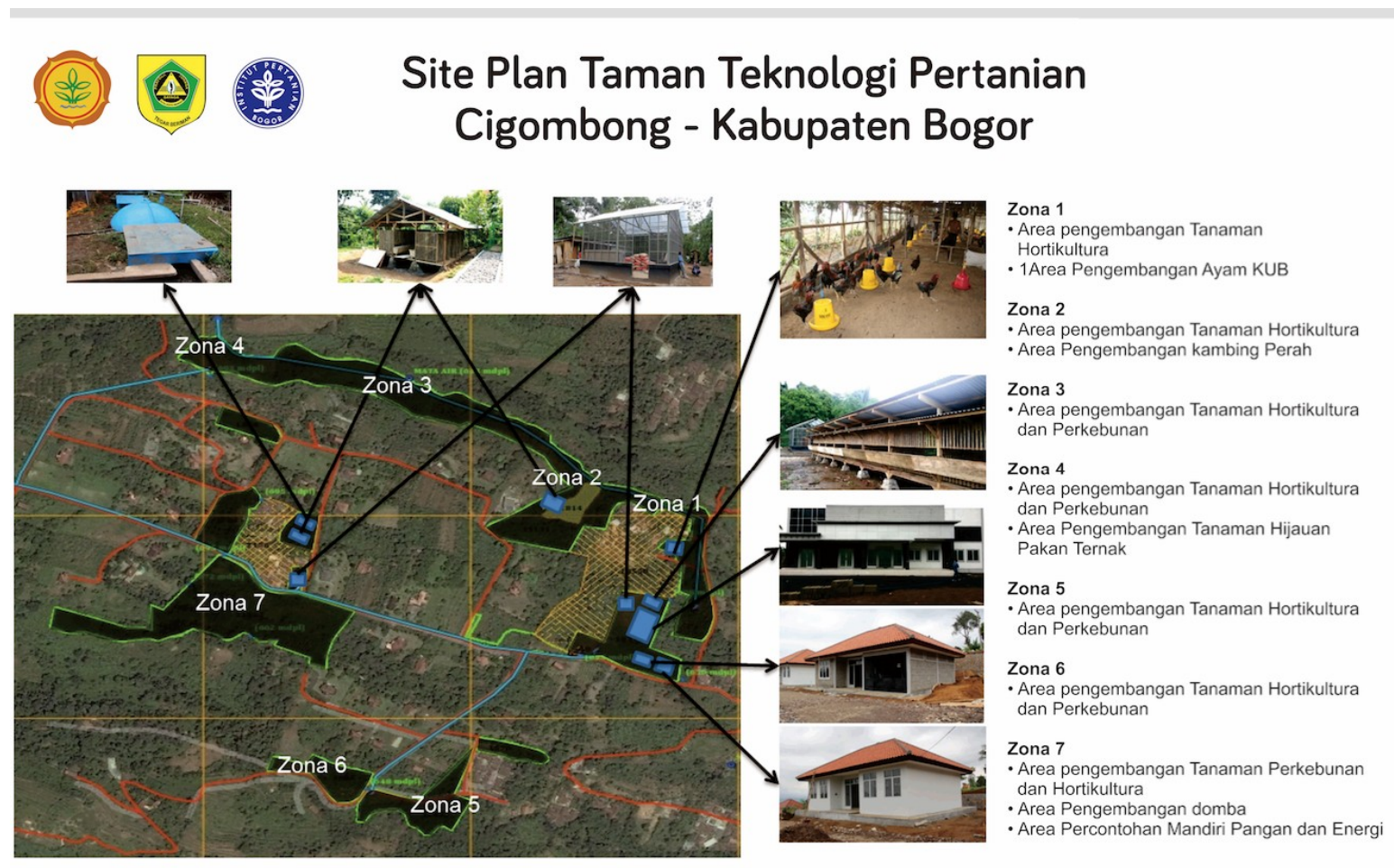

Gambar 1. Site Plan TTP Cigombong, Kabupaten Bogor - Jawa Barat (BPATP, 2015)

\section{Aspek Kalayakan Sosial Ekonomi di Peternak}

Aspek kelayakan sosial ekonomi usaha ternak ayam kampung KUB di peternak plasma cukup berpengaruh nyata dan diterima di masyarakat. Kemudian untuk sementara tenaga kerja masih dilakukan oleh peternak sendiri, sehingga belum dihitung berdasarkan usahanya. Namun dalam kegiatan usaha tenaga kerja tetap dihitung berdasarkan waktu kerja selama satu tahun. Usaha ternak ayam kampung KUB ini dilakukan dengan menggunakan DOC, harga yang diperhitungan. Pada aspek pasar ternak, di lokasi penelitian cukup baik, dan memiliki peluang pasar yang starategi. Untuk aspek teknis, usaha ayam kampung KUB memiliki lokasi yang strategis, tidak jauh dari kota, tidak terkena luasan perkotaan, sarana dan prasarana sangat mendukung untuk perkembangan usaha ayam kampung KUB. Memudahkan dalam kegiatan operasional usaha, sehingga sampai saat ini TTP Cigombong sudah nasional. Aspek manajemen pada usaha ternak ayam kampung KUB sangat layak untuk kembangkan, karena struktur organisasinya di TTP Cigombong sangat jelas dan deskripsi. 


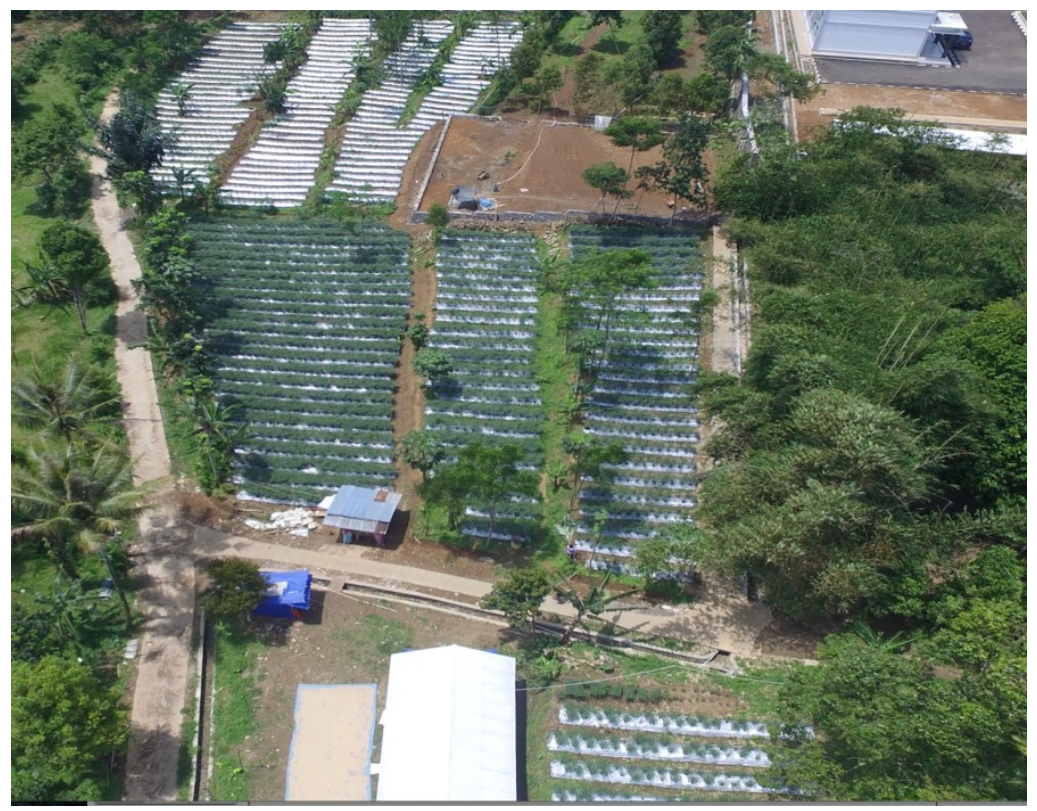

Gambar 2. Zona TTP Cigombong BPATP 2015.

Pada aspek hukum, usaha ternak ayam kampung KUB telah memiliki surat ijin usaha dari masyarakat sekitar dan dari Dinas Peternakan Kabupaten Bogor, sehingga memberikan jaminan untuk lancarnya kegiatan usaha. Dalam kegiata TTP Cogombong penaggungjawab kegiatan sudah masing-masing, baik untuk peternak inti maupun peternak plasma. Aspek sosial dan ekonomi, usaha ternak ayam kampung KUB layak untuk kembangkan, karena adanya usaha tersebut dapat menyerap tenaga kerja bagi masyarakat sekitar. Mengurangi pengangguran dan meningkatkan pendapatan masyarakat sekitar yang berperan aktif sebagai peternak plasma ayam kampung KUB, binaan peternak inti dari TTP Cigombong. Aspek lingkungan juga sangat layak untuk dijalankan, karena limbah yang ditimbulkan berupa kotoran ternak tidak menimbulkan bau, setiap hari kandang selalu dibersihkan, kotoran ternak dikumpulkan dimanfaatkan sebagai pupuk kandang untuk dilahan pertanian peternak di lingkungan sekitar.

Pada tahun 2017 peternak pelasma ayam kampug KUB sudah mendapatkan keuntungan yang sesuai dengan keinginan peternak. Ternak ayam kampung KUB di peternak plasma selain angka kematian (mortalitas) yang rendah dan cara pemeliharaan sangat mudah, tidak membutuhkan waktu yang cukup lama dan tenaga kerja yang banyak. Perkiraan modal usaha ternak ayam kampung KUB untuk pembibitan dengan rincian biaya yang dibutuhkan harus benar-benar terarah. Agar modal usaha yang dikeluarkan ole peternak dapat kembali dengan baik dan tidak meleset dari perkiraan perhitungan usaha. Hal yang paling penting pada usaha ayam kampung KUB pada DOC adalah menjaga kesehatan ayam, dengan memberikan vmenjaga kebersihan kandang, memberikan obatobatan dan vaksin, bila hal tersbeut dilakukan maka ayam kampung KUB akan terbebas dari serangan penyakit.

Ayam kampung KUB memiliki prospek yang lebih baik dan juga pemasarannya cukup luas, dapat dibutuhkan settiap saat. Harga jual ternak ayam kampung KUB baik jantan, betina relatif lebih tinggi, jika dibandingkan dengan jenis ayam yang lain. Masa panen ternak ayam kampung KUB relatif lebih cepat dan ramah terhadap lingkungan karena tidak menimbulkan bau yang begitu menyengat.

\section{Analisis Ekonomi Usaha Ayam Kampung KUB}

Rincian modal pada usaha ternak ayam kampung KUB, tidak menjadikan 
salah satu kepastian yang mutlak dengan modal yang besar. Namun peternak plasma setidaknya sudah mempunyai gambaran sebelum memulai usaha. Dalam analisis ekonomi pada usaha ternak ayam kampung KUB, dapat dihitung berdasarkan asumsi produksi selama satu tahun. Menurut Hartono et al., (2013) secara farsial dan indefeden yang dapat berpengaruh terhadap pendapatan peternak adalah jumlah pemeliharaan ternak, biaya yang dikeluarkan selama usaha. Rincian baya untuk pembuatan kandang sebesaar Rp.2.050.000/unit, penyusutan kandang selama 5 tahun sebesar Rp.410.000,-/tahun. Perlatan kandang sebesar Rp.200.000,- dan penyusutan peralatan kandang selama sebesar Rp.40.000,-/tahun. Pembelian bibit DOC ternak ayam kampung KUB sebear Rp. 10.000/ekor x 100 ekor $=$ Rp1.000.000,-. Diasumsikan untuk kematian DOC sebesar 5\%, biaya pakan sebesar Rp. 675.000,/periode dan biaya tenaga kerja peternak sebesar Rp.1.600.000/ periode.

Perkiraan keuntungan pada usaha ternak ayam kampung KUB di peternak plasma menjadi salah satu pemikiran yang hasrus diperhitungkan untung dan rugi dalam analsisi ekonomi. Lama waktu mepeliharaan ayam kampung KUB (DOC) sampai masa panen hingga 8 minggu atau 2 bulan pemeliharaan. Asumsi dalam perkiraan secara ekonomi bahwa, pendapatan peternak plasma dari hasil jual ayam kampung KUB umur 8 minggu sebanyak 95 ekor $\mathrm{x}$ harga jual sebesar Rp.40.000/ekor. Modal awal sebagai investasi masih sebesar Rp 2.050.000,- dengan modal operasional dan penyusutan kandang dan lainnya sebebsar Rp Rp.2.805.000,-. Perkiraan analisis ekonomi pada usaha ternak ayam kampung KUB di peternak plasma, modal usaha akan kembali apabila peternak plasma mendapatkan keuntungan lebih besar dari pada modal usaha yang dikeluarkan. Pada pembelian DOC peternak plasma tidak diasumsikan kedalam ongkos kirim baik luar maupun dalam, karena pada saat pengambilan DOC untuk sementara waktu, peternak plasma menerima DOC di tempat, di kirim oleh peternak inti. Analisis ekonomi pada usaha ternak ayam kampung KUB pada kelompok peternak plasma terliha pada Tabel.1.

Tabel.1, menunjukkan bahwa, nilai jual pada ternak ayam kampung KUB umur 8 minggu, peternak plasma mendapat keuntungan bersih sebesar Rp.995.000,/periode, dengan $\mathrm{B} / \mathrm{C}$ ratio sebesar 1,3 . Tidak jauh berbeda dengan hasil penelitian Wibowo dan Sartika (2011), dengan pemeliharaan ayam kampung untuk pembibitan dan penghasil DOC sebanyak

Tabel.1. Analisis usaha ternak ayam kampung KUB umur 8 minggu di peternak

\begin{tabular}{lll}
\hline A. Biaya produksi & Volue/Rp & Persen (\%) \\
\hline pembuatan kandang 1 unit @Rp.2.050.000 & 2.050 .000 & \\
peralatan kandang @Rp.200.000/paket & 200.000 & \\
penyusutan kandang 5/tahun & 410.000 & 14,61 \\
penyusutan peralatan 5/tahun & 40.000 & 1,42 \\
bibit DOC ayam kampung KUB 100 ekor @Rp.10.000 & 1.000 .000 & 35.65 \\
pakan (0-2 bulan) (100 x 1,5 x 4,500) & 675.000 & 24.06 \\
kesehatan ternak@Rp.150.000/paket & 150.000 & 5.98 \\
biaya listri @Rp.50.000 x 2 bulan & 100.000 & 3.56 \\
sekam @Rp.10 kg x Rp.3.000 & 30.000 & 1.07 \\
biaya tenaga kerja peternak @Rp.800.000/perode panen & 1.600 .000 & 57.04 \\
Jumlah baya produksi & 2.805 .000 & 100 \\
\hline B.Keuntungan & & \\
penjualan (100x5\%) x harga jual @Rp.40.000.000/ekor & 3.800 .000 & \\
keuntngan kotor & 3.800 .000 & \\
keuntngan bersih/periode panen & 995.000 & \\
B/C & 1,3 & 100 \\
\hline
\end{tabular}


360 ekor/3 bulan peternak mendapatan keuntungan sebebsar Rp 3.449.097,-/periode dengan B/C 1,51. Hasil penelitian Dewanti dan Sihombing (2012) pada usaha ayam buras di Kecamatan Tengalombo Kabupaten Pacitan keuntungn peternak sebebsar Rp. 1.383.358,-/tahun dengan rata-rata pejualan 89 ekor. Hasil analisis dengan pendekatan $\mathrm{B} / \mathrm{C}$ ratio menunjukkan bahwa usaha ternak ayam kampung KUB dengan pemeliharaan selama 8 minggu secara ekonomi finansial layak untuk diusahakan kembali.

Menurut Wiranata et al., (2017) bahwa faktor yang paling dominan pengaruhnya terhadap tingkat keuntungan yaitu biaya pakan, biaya manajemen dan produksi ayam, sekitar 98\% diperthitungkan dan 2\% lain di luar perhitungan. Usaha dapat dilakuan jika semua harga faktor produksi dan hasil produksi tidak mengalami perubahan harga jaul maupun beli. Menurut Nataamijaja (2010) dan Sudrajat dan Isyanto (2018), bahwa, upaya pengembangan usaha ternak ayam kampung dapat diharapkan selain menggairahkan peternak untuk terus berusaha, juga dapat meningkatkan nilai ekonomi peternak. Demikian pula aspek teknis antara lain kematian ayam karena benacana alam yang tidak dapat diprediksi. Usaha dapat dilakuan jika semua harga faktor produksi dan hasil produksi tidak mengalami perubahan harga jaul maupun beli. Dengan menggunakan teknologi dan inovasi, maka sebagian besar masyarakat peternak, akan meningkat pada kondisi keluarga yang cukup.

\section{KESIMPULAN}

Peran TTP Cigombong, seyogyanya menjadi fokus perhatian, karena TTP Cigombong sampai saat ini dapat dimainkan sebagai peran besar wahana untuk usaha pengembangan peternakan (ayam kampung KUB, kambing perah, domba, pertanian, perikanan dan usaha lainnya). Usaha ternak ayam kampung KUB yang berorientasi komersial, diperlukan perencanaan serta penanganan yang lebih detail, agar usaha mendapatkan keuntungan yang optimal.
Nilai jual ternak ayam kampung KUB umur minggu 8, keuntungan bersih sebesar Rp.995.000,-/peterak plasma $\mathrm{B} / \mathrm{C}$ ratio 1,3. Hasil analisis dengan pendekatan $\mathrm{B} / \mathrm{C}$ ratio menunjukkan bahwa usaha ternak ayam kampung KUB dengan pemeliharaan umur 8 minggu, secara ekonomi finansial layak untuk diusahakan kembali.

\section{DAFTAR PUSTAKA}

Anggraeni, A. 2016. Pendampingan, koordinasi, bimbingan dan dukungan teknologi UPSUS Daging, TSP, TTP, dan Komoditas Utama Kementan. Lapaoran kegiatan RDHP tahaun 2016. Desember 2016, hal 161

[BPATP] Balai Penelitian Alih Teknologi Pertanian. 2015. Grand Desain, Taman Telnologi Pertanian Cigombong Kabupaten Bogor, Jakarta Februari 2015, Haal.1-103

Adawiyah, C. R. dan S. Rusdiana. 2016. Usahatani tanaman pangan dan peternakan dalam analisis ekonomi di petani. Jurnal Riset Agribisnis dan Peternakan. 1(2):37-49.

Badan Litbang Pertanian. 2015. Pedoman Umum Pengembangan Taman Sains dan Teknologi Pertanian (TSTP). Badan Penelitian dan Pengembangan Pertanian, Kementerian Pertanian.

Badan Litbang Pertanian. 2015. Surat Keputusan No 31/Kpts/OT.050/I/01/2015 tentang Pembentukan Tim Pengelola Laboratorium Inovasi Pertanian Badan Penelitian dan Pengembangan Peternakan. Badan Penelitian dan Pengembangan Pertanian. Kementerian Pertanian, Desember 2015.

Dewanti, R. dan G. Sihombing. 2012. Analisis pendapatan usaha peternakan ayam buras (Studi Kasus di Kecamatan Tegalombo Kabupaten 
Pacitan), Buletin Peternakan-UGM 36 (1):48-56.

Ilham, U., Hermanto, S., dan D.S. Priyarsono. 2008. Efektivitas kebijakan harga pangan terhadap ketahanan pangan. Jurnal Agro Ekonomi PSEKP, Mei 2008, 24(2):157-177.

Krismawati Amik dan Andy Bharmana. 2006. Kajian penerapan teknologi usahatani nilai (Pogostemon cablin Benih di lahan kering Kalimantan Selatan. Jurnal Pengkajian dan Pengembangan Teknologi Pertanian. 9(2):160-167.

Kusnadi, E. Juari dan B. Setiadi 2006. Analisis potensi wilayah peternakan di Pulau Sumatera, Prosiding Seminar Nasional Peternakan, Balai Pengkajian Teknologi Sumatera Selatan Fakultas Peternakan Universitas Padang Mangatas, Padang, 11-12 September 2006, hal: 32-41.

[Kementan] Kementerian Pertanian. 2012. Organisasi dan Tata Kerja Balai Penelitian Ternak, Keputusan Menteri Pertanian Nomor: 71/Kpts/OT.210/1/2002. Jakarta Nopember 2012.

Loing, C. Jeane dan A. Makalew. 2016. Analisis finansial usaha ternak ayam kampung di Kecamatan Kawangkoan kawasan agropolitan Kabupaten Minahasa, Kurnal LPPM Bidang Sains dan Teknologi. 3(1):51-56.

Nataamijaya, A. Gozali. 2010. Pengembangan potesi usaha ternak ayam lokal untuk menunjang kesejahteraan petani. Jurnal Littbang Pertanian. 34(3):131-138.

Nurhapsa, Yusriadi dan Nurhaedah. 2017. Campuran pakan herbal untuk ternak ayam kampung Jurnal Manajemen Jurnal Equilibrium. 6(1):29-33.

Muzayyanah, M., A.U. S. Nartini dan R.Widiati. 2016. Analisis keputusan rumah tangga dalam mengkonsumsi pakan sumber protein hewani asal ternak dan non ternak : Studi Kasus di Propinsi D.I. Yogyakarta. Buletin Peternakan UGM. 41(2):203-211.

Rosganda, E. dan S. Rusdiana. 2012. Peluang usaha ternak ayam kampung dan manajemen usaha pada petani di pedesaan. Pros. Seminar Nasinal Unggal Lokal, Tim review Rasali, M. Matondang, L. Prasetiyo dan S.Iskandar, Puslitbangak, Jakarta 4 Nopember 2012, hal: 104-109.

Supriyati dan E. Suryani. 2006. Peran peluang dan kendala pengembangan agroindustri d Indonesia. Forum Agro Ekonomo, FAE, PSEKP. 24(2):92-106.

Sartika,T. dan S.B. Gunwan. 2007. Karakateristik sifat-sifat produktivitas ayam kampung betina fase produksi pada populasi dasar seleksi. Prosiding Seminar Nasional Teknologi Peternakan dan Vteriner, Bogor, 21-22 Agustus 2007, hal: 576-58.

Sudrajat dan A.Y. Isyanto. 2018 Keragaan peternakan ayam sentul di Kabupaten Ciamis, Mimbar Agribsnis. Jurnal Pemikiran Masyarakat Ilmiah Berwawasan Agribisnis. 4(2):237253.

Wibowa, B. dan D. Sartika. 2011. Analisis kelayakan usaha penggemukan ayam kampung (lokal) di tingkat petani Studi kasus kelompok peternak ayam kampung "Barokah" di Ciamis. Posiding Seminar Nasional Peternaan dan Veteriner, Bogor, 3-4 Agustus 2011. Hal: 699-704.

Wiranata, M. A., J. I. Sanyoto dan H. Subagja. 2017. Analisis profitabilitas usaha peternakan ayam kampung super di Kabupaten Jember, Jurnal Ilmu Peternakan dan Terapan. 1(1): 31-38.

Zakaria, A. 2014. Evaluasi adopsi teknologi budidaya dan kelayakan usahatani padi di Propinsi Sulawesi Selatan, Jurnal Sosial Ekonomi Pertanian dan Agribisnis. 10(2):217-228. 